\title{
Hubungan Obesitas Sentral Dengan Hipertensi Pada Penduduk Usia 25-65 Tahun
}

\author{
Gusni Rahma ${ }^{1}$, Gusrianti ${ }^{2}$ \\ 1,2, Program Studi Kesehatan Masyarakat, STIKes Alifah Padang \\ Jl. Khatib Sulaiman No.52B, Kel. Ulak Karang Sel., Padang Utara, Kota Padang, Sumatera Barat 25134 \\ Email: 'gusnirahma@gmail.com, ${ }^{2}$ gusrianti819@gmail.com
}

\begin{abstract}
Abstrak
Di Indonesia prevalensi hipertensi cenderung tinggi, terdapat beberapa faktor yang berkontribusi terhadap munculnya hipertensi. Salah satunya adalah obesitas sentral. Obesitas sentral merupakan kondisi lemak berlebih yang terpusat di daerah perut (intra-abdominal fat). Beberapa penelitian menemukan bahwa hipertensi banyak ditemukan pada individu dengan obesitas sentral daripada obesitas umum. Tujuan penelitian ini adalah mengetahui hubungan obesitas sentral dengan kejadian hipertensi pada penduduk usia 25-65 tahun di wilayah kerja Puskesmas Belimbing, Kota Padang. Penelitian ini menggunakan pendekatan kuantitatif dengan desain studi cross sectional dengan sampel 107 penduduk di wilayah kerja Puskesmas Belimbing. Analisis data univariat dalam bentuk distribusi frekuensi dan bivariat dengan uji chi-square. Hasil penelitian menunjukkan $31 \%$ penduduk mengalami hipertensi dan 43,9\% penduduk dengan obesitas sentral. Penduduk dengan obesitas sentral berpeluang 3,63 (95\% CI 1,52 - 8,68) kali mengalami hipertensi dibandingkan penduduk tidak obesitas sentral $(p=0,003)$.
\end{abstract}

Kata kunci: Obesitas sentral, Hipertensi, Proporsi

\section{Association of Central Obesity With Hypertension in Population Ages 25- 65 Years}

\begin{abstract}
In Indonesia, the prevalence of hypertension is very high; there are several factors that contribute to hypertension. One of them is central obesity. Central obesity is excess fat that has concentrated in the abdominal area (intra-abdominal fat). Some studies suggest that hypertension has more commonly found in centrally obese individuals compared to general obese groups. The purpose of this study was to the association central obesity relationship with the incidence of hypertension in the population aged 25-65 years in the area of Belimbing Health Center, Padang City. This study uses a quantitative crosssectional study design with a sample of 107 residents in the area of Belimbing Health Center. Univariate data analysis in the form of frequency distribution and bivariate with chi-square test. The results showed $31 \%$ of the population with hypertension and $43.9 \%$ of the population with central obesity. The population among people 25-65 years of central obesity 3.63 times (95\% CI 1.52 - 8.68) a chance to get hypertension compared to non-central obese $(p=0.003)$.
\end{abstract}

Keywords: Central obesity, Hypertension, The prevalence 


\section{PENDAHULUAN}

Hipertensi merupakan Penyakit Tidak Menular (PTM) yang menjadi perhatian Badan Kesehatan Dunia (World Health Organisation/WHO). Prevalensi hipertensi pada negara berkembang lebih tinggi dibandingkan dengan prevalensi hipertensi di negara maju (WHO, 2015). Hal ini disebabkan oleh beberapa faktor, diantaranya belum ada sistem deteksi dini dan masih kurangnya pemanfaatan akses pelayanan kesehatan. Selain itu, banyak orang di negara berkembang tidak menyadari adanya hipertensi (World Health Organization (WHO), 2015). Padahal, jika hipertensi dapat dikendalikan maka risiko kematian dan kecacatan akibat penyakit jantung dan stroke dapat ditekan secara signifikan (Rahajeng \& Tuminah, 2011).Oleh karena itu, pencegahan, deteksi dini, pengobatan dan pengendalian hipertensi merupakan prioritas kesehatan yang penting di seluruh dunia (WHO, 2015). Di Indonesia prevalensi hipertensi cenderung tinggi. Berdasarkan Riset Kesehatan Dasar (Riskesdas)tahun 2013, prevalensi hipertensi pada penduduk umur lebih dari 18 tahun sekitar 25,8\% dan meningkat sekitar $34,1 \%$ pada tahun 2018 berdasarkan Riskesdas tahun 2018 (Kemenkes, 2018). Di Sumatera Barat prevalensi hipertensi berdasarkan hasil Riskesdas Tahun 2013 pada penduduk usia 18 tahun atau lebih sekitar 22,6 \%(Kemenkes, 2013). Di Kota Padang, hipertensi merupakan penyakit No.2 terbanyak berdasarkan laporan puskesmas yang dirangkum melalui e-Puskemas (Dinkes Kota Padang, 2017).

Faktor risiko hipertensi dibedakan menjadi 2 (dua) faktor yaitu faktor yang tidak dapat diubah seperti keturunan, ras, jenis kelamin, dan umur. Faktor yang dapat diubah meliputi diet tidak sehat, obesitas, stress, merokok, kurang aktifitas fisik, konsumsi alkohol berlebih, konsumsi garam berlebih, kolesterol dan diabetes mellitus (WHO, 2015)(CDC, 2014b)(CDC, 2014a).

Sebagai salah satu faktor risiko hipertensi, obesitas juga menjadi isu kesehatan tersendiri di Indonesia. Prevalensi obesitas sentral berdasarkan Riskesdas Tahun 2013 adalah sebesar 26,6\% (Kemenkes, 2013). Obesitas sentral merupakan kondisi lemak yang berlebih terpusat di daerah perut (intra-abdominal fat). Beberapa penelitian menyatakan bahwa lingkar perut adalah indikator terbaik untuk pengukuran obesitas untuk menentukan risiko penyakit kardiovaskular (Shrivastava, 2015). Selain itu, Lingkar perut menjadi predikor yang lebih baik terhadap risiko obesitas untuk orang asia, dimana orang asia cenderung memiliki presentase lemak dan tubuh visceral yang tinggi dibandingkan ras yang lain (Misra \& Khurana, 2011).

Obesitas sentral berhubungan dengan hipertensi melalui beberapa mekanisme. Adanya peningkatan lemak di sekitar abdominal mengakibatakan penurunan adiponektin sehingga proses aterosklerosis dapat mudah terjadi. Mekasnisme peningkatan aktivitas simpatis lainnya yaitu kegagalan fungsi dari sensitivitas baroreseptor, peningkatan asam lemak bebas, angiotensin II, insulin dan leptin dapat meningkatkan peningkatan resistensi vaskuler yang dapat menyebabkan terjadinya hipertensi (Kaplan \& Victor, 2014).

Prevalensi hipertensi meningkat sejalan dengan perubahan gaya hidup seperti obesitas sentral, Hipertensi menjadi masalah kesehatan masyarakat dan akan menjadi masalah yang lebih besar jika tidak ditanggulangi sejak dini. Tujuan penelitian ini adalah untuk mengetahui hubungan obesitas sentral dengan kejadian hipertensi pada penduduk usia 25-65 tahun. Hasil penelitian diharapkan dapat memberikan tambahan evidence based untuk kebijakan penanggulangan PTM dan menjadi bahan pertimbangan dalam merancang intervensi pengendalian hipertensi untuk penduduk khususnya di Kota Padang.

Tujuan penelitian ini adalah mengetahui hubungan obesitas sentral dengan kejadian hipertensi pada penduduk usia 25-65 tahun di wilayah kerja Puskesmas Belimbing, Kota Padang.

\section{METODE PENELITIAN}

Penelitian ini menggunakan pendekatan pendekatan kuantitatif dengan desain studi cross sectional. Pengumpulan data dilakukan dari bulan Juli sampai dengan Agustus 2019 di wilayah kerja Puskesmas Belimbing di Kota Padang.

Populasi adalah semua penduduk yang tercatat di wilayah kerja Puskesmas Belimbing di Kota Padang dan peneliti mengambil sampel sebanyak 107 penduduk berdasarkan perhitungan menggunakan rumus Lemeshow. 
Kriteria inklusi dari responden yaitu penduduk usia 25-65 tahun yang bertempat tinggal di wilayahkerja Puskesmas Belimbing Kota Padang. Pengambilan sampel dilakukan dengan menggunakan teknik purposive sampling.

Variabel yang diteliti dalam penelitian ini adalah adalah kejadian hipertensi (dependen) dan obesitas sentral (independen). Kriteria hipertensi adalah penderita yang mempunyai tekanan darah sistolik $\geq 140 \mathrm{mmHg}$ dan atau tekanan darah diastolik $\geq 90 \mathrm{mmHg}$ (Hipertensi stage 2) berdasarkan American Heart Association (AHA) tahun 2017(Whelton et al., 2017) sedangkan kriteria obesitas sentral berdasarkan International Diabetes Federation (IDF) tahun 2006 cut off point lingkar perut untuk wilayah Asia pada laki-laki $>90 \mathrm{~cm}$ dan pada perempuan $>80 \mathrm{~cm}$ (IDF, 2006).

Analisis data univariat dalam bentuk distribusi frekuensi dan analisis bivariat dengan uji chi square. Data dianalisis menggunakan software SPSS 17.0.

\section{HASIL DAN PEMBAHASAN}

Distribusi frekuensi kejadian hipertensi dapat di lihat pada tabel 1 .

Tabel 1. Distribusi Frekuensi Hipertensi dan Obesitas Sentral

\begin{tabular}{lcc}
\hline \multicolumn{1}{c}{ Variabel } & $\begin{array}{c}\mathbf{f} \\
(\mathbf{n}=\mathbf{1 0 7})\end{array}$ & $\mathbf{\%}$ \\
\hline Hipertensi & & \\
Ya & 31 & 29,0 \\
Tidak & 76 & 71,0 \\
Obesitas Sentral & & \\
Ya & 47 & 43,9 \\
Tidak & 60 & 56,1 \\
\hline
\end{tabular}

Berdasarkan Tabel 1 dapat dilihat bahwa dari 107 responden didapatkan proporsi kejadian hipertensi yaitu sebesar 29\%, sedangkan proporsi obesitas sentral sebesar 43,9\%.

Hubungan obesitas sentral dengan hipertensi dapat dilihat pada tabel 2.

Tabel 2. Hubungan Obesitas Sentral dengan Hipertensi

\begin{tabular}{|c|c|c|c|c|c|c|}
\hline \multirow{3}{*}{$\begin{array}{l}\text { Obesitas } \\
\text { Sentral }\end{array}$} & \multicolumn{4}{|c|}{ Hipertensi } & \multirow{3}{*}{$\begin{array}{c}\text { POR } \\
(95 \% \mathrm{CI})\end{array}$} & \multirow{3}{*}{$P$-value } \\
\hline & \multicolumn{2}{|c|}{ Ya } & \multicolumn{2}{|c|}{ Tidak } & & \\
\hline & f & $\%$ & $\mathbf{f}$ & $\%$ & & \\
\hline Ya & 21 & 53,8 & 18 & 46,2 & 3,63 & \\
\hline Tidak & 13 & 19,1 & 55 & 80,9 & $(1,52-8,68)$ & 0,003 \\
\hline
\end{tabular}

Pada tabel 2, dapat di lihat proporsi kejadian hipertensi pada responden yang obesitas sentral sebesar $53,8 \%$ atau dua kali lebih besar dibandingkan dengan responden yang tidak obesitas sentral. hasil analisis bivariat diketahui bahwa obesitas sentral berhubungan secara bermakna dengan kejadian hipertensi. Dari uji statistik diperoleh nilai POR sebesar 3,63 (95\% CI: 1,52 - 8,68), artinya responden dengan obesitas sentral berpeluang 3,63 kali mengalami hipertensi dibandingkan dengan responden yang tidak obesitas sentral.

Hasil penelitian menunjukkan proporsi hipertensi di wilayah kerja Puskesmas Belimbing (29\%) lebih rendah dibandingkan angka Nasional (34,1\%), Namun, lebih tinggi jika dibandingkan dengan provinsi Sumatera Barat $(22,6 \%)$ (Kemenkes, 2018). Sedangkan penelitian yang dilakukan oleh Van Minh et al di Purwerejo, prevalensi hipertensi pada penduduk usia 25-65 tahun adalah sebesar 12,8\% (Van Minh et al., 2009). Perbedaan 
tersebut terjadi karena kemungkinan adanya perbedaan faktor risiko hipertensi. Meliputikebiasaan makan, seperti asupan sodium tinggi atau rendah kalium,konsumsi alkohol tinggi, rendahnya aktivitas fisik dankelebihan berat badan(Chockalingam, Campbell, \& George Fodor, 2006).

Salah satu faktor yang berkontribusi terhadap tingginya prevalensi hipertensi di Indonesia adalah peningkatan prevalensi kelebihan berat badan dan obesitas(Hussain, Al Mamun, Reid, \& Huxley, 2016). Pada penelitian ini ditemukan, proporsi obesitas sentral lebih tinggi dibandingkan dengan angka Nasional (43,9\% vs 26,6\%). Sedangkan proporsi kejadian hipertensi pada responden yang obesitas sentral sebesar $53,8 \%$ atau dua kali lebih besar dibandingkan dengan responden yang tidak obesitas sentral.

Pada analisis ini ditemukan, hubungan obesitas sentral dengan kejadian hipertensi yaitu sebesar 3,63 (95\% CI: 1,52 - 8,68), artinya responden dengan obesitas sentral mempunya peluag 3,63 kali lebih besar untuk mengalami hipertensi dibandingkan dengan responden yang tidak obesitas sentral. Berdasarkan penelitian sebelumnya, menyebutkan adanya hubungan yang bermakna antara obesitas sentral dengan kejadian hipertensi (Hussain et al., 2016). Berdasarkan penelitian pada penduduk dewasa oleh Rahajeng dan Tuminah, orang dengan obesitas sentral berisiko 1,54 kali lebih besar untuk menderika hipertensi dibandingkan dengan orang yang tidak obesitas sentral dengan $(95 \%$ CI: 1,36-1,44). Perbedaan penelitian ini dengan penelitian Rahajeng dan Tuminah disebabkan oleh tidak ada variabel kovariat yang diikutsertakan dalam penelitian ini.

Pada orang dengan obesitas sentral terapat beberapa mekanisme yang dapat menimbulkan hipertensi. Lemak intra abdomen memberikan peranan penting pada kenaikan tekanan darah. Hal ini dikarenakan pada orang dengan lingkar abdomen besar (lemak intra abdomen tinggi) terjadi penurunan kadar adiponektin sebagai antiaterogenik, sehingga dengan menurunnya kadar protein spesifik ini maka peningkatan tekanan darah dapat terjadi (Olinto et al., 2004).

Adanya penurunan adiponektin, maka proses aterosklerosis dapat mudah terjadi. Aterosklerosis merupakan suatu keadaan pembuluh darah dinding arteri sedang dan besar menjadi kaku dan menebal sebagai akibat lesi lemak (plak ateromatosa) pada permukaan dalam dinding arteri. Hilangnya distensibilitas arteri (arteri menjadi kaku) menyebabkan tekanan darah meningkat dan darah tidak dapat mengembang saat darah dari jantung melewati arteri tersebut (Kaplan \& Victor, 2014).

Hipertensi jika dibiarkan tidak terkendali dapat berakibat fatal karena dapat menyebabkan serangan jantung, stroke, gagal ginjal, kebutaan dan gangguan kognitif (WHO, 2015). Besarnya dampak hipertensi terhadap berbagai penyakit tidak menular menunjukkan perlunya penanggulangan hipertensi dengan cara pengendalian faktor risiko yang berkontribusi terhadap terjadinya hipertensi yaitu obesitas sentral, dengan cara menerapkan pola hidup sehat.

\section{SIMPULAN}

Berdasarkan hasil penelitian disimpulkan bahwa orang dengan obesitas sentral berpeluang 3,63 kali lebih besar untuk mengalami hipertensi dibandingkan dengan orang yang tidak obesitas sentral. Peneliti merekomendasikan masyarakat untuk dapat melaksanakan pola hidup sehat serta rutin untuk melaksanakan skrining obesitas sentral dan deteksi dini hipertensi pada Pos Pembinaan Terpadu (Posbindu) PTM atau Puskesmas. Salah satu pola hidup sehat yang dapat dilakukan dalam mencegah obesitas sentral dan hipertensi adalah melakukan aktivitas fisik ringan dengan berjalan kaki minimal 30 menit dalam sehari atau minimal 3 kali dalam seminggu.

\section{UCAPAN TERIMA KASIH}

Terima kasih kepada pihak Puskesmas Belimbing Kota Padang yang telah memberikan pengalaman dan pengetahuan yang bermanfaat bagi penulis. Serta pihak lain yang turut membantu dalam menyelesaikan penelitian ini.

\section{DAFTAR PUSTAKA}

CDC. (2014a). Behaviors That Increase Risk for High Blood Pressure. Retrieved December 20, 2017, from https://www.cdc.gov/bloodpressure/beha vior.htm

CDC. (2014b). Family History and Other 
Characteristics That Increase Risk for High Blood Pressure. Retrieved from https://www.cdc.gov/bloodpressure/famil y_history.htm

Chockalingam, A., Campbell, N. R., \& George Fodor, J. (2006). A worldwide epidemic of hypertension. Canadian Journal of Cardiology, 22(7), 553-555. https://doi.org/10.1016/S0828282X(06)70275-6

Dinkes Kota Padang. (2017). Profil Kesehatan Kota Padang 2017. Retrieved from http://www.depkes.go.id/resources/downl oad/profil/PROFIL_KAB_KOTA_2017/ 1371_Sumbar_Kota_Padang_2017.pdf

Hussain, M. A., Al Mamun, A., Reid, C., \& Huxley, R. R. (2016). Prevalence, awareness, treatment, and control of hypertension in Indonesian adults aged $\geq 40$ years: Findings from the Indonesia Family Life Survey (IFLS). PLoS ONE, 11(8), 1-16. https://doi.org/10.1371/journal.pone.0160 922

IDF. (2006). IDF Diabetes Atlas (6th ed.). Retrieved from https://idf.org/elibrary/epidemiology-research/diabetesatlas.html

Kaplan, N. M., \& Victor, R. G. (2014). Kaplan's clinical hypertension: Eleventh edition. Kaplan's Clinical Hypertension: Eleventh Edition. https://doi.org/10.1097/00132580200211000-00012

Kemenkes. (2013). Riset Kesehatan Dasar (RISKESDAS) 2013. Laporan Nasional 2013, 1-384. https://doi.org/1 December 2013

Kemenkes. (2018). Hasil Utama Riset Kesehatan Dasar 2018. Retrieved from http://www.depkes.go.id/resources/downl oad/info-

terkini/materi_rakorpop_2018/Hasil

Riskesdas 2018.pdf

Misra, A., \& Khurana, L. (2011). Obesityrelated non-communicable diseases: South Asians vs. White Caucasians. International Journal of Obesity, 35(2), 167-187.

https://doi.org/10.1038/ijo.2010.135

Olinto, M., Nacul, L., Gigante, D., Costa, J., Menezes, A., \& Macedo, S. (2004). Waist circumference as a determinant of hypertension and diabetes in Brazilian women: a population-based study. Public Health Nutrition, 7(5), 629-635. https://doi.org/10.1079/PHN2003582

Shrivastava et al. (2015). A systematic review of the association of abdominal obesity in children and adolescents with cardiometabolic risk factors. Journal of research in medical sciences: the official journal of Isfahan University of Medical Sciences. (Vol. 20). J Res Med Sci. 2015 Mar; 20(3): 294-307. https://doi.org/PMCID: PMC4468236

Van Minh, H., Soonthornthada, K., Ng, N., Juvekar, S., Razzaque, A., Ashraf, A., ... Kanungsukkasem, U. (2009). Blood pressure in adult rural IN-DEPTH population in Asia. Global Health Action, 2(1), 2010. https://doi.org/10.3402/gha.v2i0.2010

Whelton, P. K., Carey, R. M., Aronow, W. S., Casey, D. E., Collins, K. J., Dennison Himmelfarb, C., ... Wright, J. T. (2017). Guideline for the Prevention, Detection, Evaluation, and Management of High Blood Pressure in Adults: A Report of the American College of Cardiology/American Heart Association Task Force on Clinical Pr. Hypertension (Dallas, Tex.: 1979), HYP.0000000000000065.

https://doi.org/10.1161/HYP.0000000000 000065

World Health Organization (WHO). (2015). Hypertension. Retrieved August 1, 2019, from https://www.who.int/newsroom/fact-sheets/detail/hypertension 